\title{
ESTIMASI PERCEPATAN TANAH MAKSIMUM DAN INTENSITAS GEMPA DI KOTA PADANG BERDASARKAN SKENARIO GEMPABUMI DI MEGATHRUST MENTAWAI MENGGUNAKAN METODE DETERMINISTIK
}

\author{
Mahesa Ragil Syofyan ${ }^{1}$, Helfia Edial ${ }^{2}$ \\ Program Studi Geografi, \\ Fakultas Ilmu Sosial, Universitas Negeri Padang \\ Email: agilsyofyan@gmail.com
}

\begin{abstract}
Abstrak
Penelitian ini bertujuan untuk mengetahui 1). persebaran nilai percepatan tanah maksimum (PGA), dan 2). persebaran nilai intensitas gempa (MMI) di Kota Padang berdasarkan skenario gempabumi di megathrust Mentawai pada zona subduksi. Adapun metode yang digunakan ialah deskriptif dengan pendekatan kuantitatif. Sehingga didapatkan hasil berupa pesebaran nilai PGA dengan rentang antara $0,25 \mathrm{~g}-0,72 \mathrm{~g}$. Nilai percepatan tanah maksimum tertinggi dengan rentang 0,46-0,72 g mencakup Kecamatan Nanggalo, Kuranji, Padang Utara Padang Timur, Padang Barat, dan Padang Selatan, sedangkan nilai percepatan tanah maksimum terendah dengan rentang 0,250,26 g mencakup kecamatan Lubuk Kilangan dan Kecamatan Pauh. Persebaran nilai intensitas gempa (MMI) di Kota Padang akibat gempabumi pada zona subduksi Mentawai dengan kedalaman $10 \mathrm{~km}$ dan kekuatan gempa 8,9 Mw memiliki nilai 7 MMI dan 8 MMI.
\end{abstract}

Kata Kunci : Percepatan Tanah Maksimum (PGA), Intensitas Gempa (MMI), Megathrust Mentawai, Zona Subduksi.

\begin{abstract}
This research aims to 1). the distribution of peak ground acceleration (PGA) values, and 2). the distribution of earthquake intensity values (MMI) in Padang City based on the earthquake scenario in the Mentawai megathrust at the subduction zone. The method used is descriptive with a quantitative approach. So that the results obtained in the form of spreading PGA values with a range between $0.25 \mathrm{~g}-0.72 \mathrm{~g}$. The highest peak ground acceleration (PGA) values ranged from 0.46-0.72 g including Nanggalo, Kuranji, Padang Utara Padang Timur Sub-Districts, Padang Barat, and Padang Selatan, while the lowest peak ground acceleration (PGA) range from 0.25-0.26 $\mathrm{g}$ includes Lubuk Kilangan sub-district and Pauh sub-district The distribution of earthquake intensity values (MMI) in Padang City due to earthquakes in the Mentawai subduction zone with a depth of $10 \mathrm{~km}$ and earthquake strength of $8.9 \mathrm{Mw}$ has a value of $7 \mathrm{MMI}$ and $8 \mathrm{MMI}$.
\end{abstract}

Keywords: Peak Ground Acceleration (PGA), Earthquake Intensity (MMI), Megathrust Mentawai, Subduction Zone.

\footnotetext{
${ }^{1}$ Mahasiswa Program Studi Geografi

${ }^{21}$ Dosen Jurusan Geografi Fakultas Ilmu Sosial Universitas Negeri Padang
} 


\section{PENDAHULUAN}

Indonesia adalah negara rawan gempabumi. Hal ini disebabkan oleh adanya pertemuan 3 lempeng aktif, yaitu dari Lempeng Eurasia yang bergerak relatif ke arah tenggara dengan kecepatan kurang lebih 0,4 cm/tahun, Lempeng Indo-Australia yang bergerak relatif ke arah utara dengan kecepatan kurang lebih $7 \mathrm{~cm} /$ tahun dan Lempeng Pasifik yang bergerak relatif kearah barat dengan kecepatan kurang lebih 11 cm/tahun (Minster dan Jordan, 1978). (Minster dan Jordan, 1978); Husrin et al (2013). menjelaskan bahwa di kawasan Barat Indonesia interaksi berlangsung antara Lempeng Eurasia dan Lempeng Indo-Australia yang membentang di sebelah barat Pulau Sumatera menerus ke selatan Pulau Jawa hingga Nusa Tenggara salah satunya wilayah yang terkena akibat interaksi lempeng tersebut adalah Sumatera Barat.

Sumatera Barat secara tektonik merupakan daerah rawan gempabumi karena berada di pertemuan lempeng Indo-Australia yang menunjam ke bawah Lempeng Eurasia yang membentuk jalur gempabumi. Kawasan gempabumi di Sumatera Barat berada pada daerah subduksi, Sesar Mentawai dan Sesar Sumatera (Novita, 2008). Hemon (2016).

Sejarah mencatat semenjak tahun 1822, Provinsi Sumatera Barat sudah mengalami gempabumi. Hal ini terjadi karena Sumatera Barat berada dekat dengan lempeng aktif (Penunjaman Lempeng Samudera Hindia). Kota Padang pernah mengalami 19 kali gempabumi dengan besar guncangan $\mathrm{V}$ hingga IX skala MMI (Peta Sumber
Dan Bahaya Gempa Indonesia Tahun 2017); Husrin et al (2013).

Setiap kejadian gempabumi yang terjadi memiliki satu nilai percepatan tanah pada wilayah tersebut. Percepatan tanah maksimum atau Peak Ground Acceleration (PGA) adalah nilai percepatan tanah terbesar di suatu tempat yang diakibatkan oleh getaran gempa bumi dalam periode waktu tertentu (Hadi, 2012).

Bencana gempabumi dapat di minimalisir dengan upaya mitigasi secara dini dan optimal, salah satu upaya mitigasi yang perlu dilakukan adalah dengan membuat peta dampak gempa yang bermanfaat dalam menggambarkan efek gempa pada suatu lokasi yang akan membantu dalam rangka antisipasi dan minimalisasi korban jiwa maupun kerugian materi. (Sieh dan Natawidjaja, 2000); Husrin dkk (2015).

Penelitian ini bertujuan untuk membuat suatu sifat, gambaran atau lukisan secara sistematis, faktual, dan akurat mengenai fakta-fakta, sifat-sifat, serta hubungan antar fenomena yang diselidiki yang berupa pesebaran nilai percepatan tanah maksimum (PGA) dan nilai intensitas gempa (MMI) di Kota Padang.

\section{METODE PENELITIAN}

\section{Jenis Penelitian}

Berdasarkan latar belakang, permasalahan dan tujuan penelitian metode penelitian yang digunakan adalah metode deskriptif kuantitatif. Menurut Moh. Nazir (2013), metode deskriptif adalah suatu metode dalam meneliti status kelompok manusia, suatu objek, suatu set kondisi, suatu sistem pe- 
mikiran, ataupun suatu kelas peristiwa pada masa sekarang.; Juitu et al (2018).

Lokasi dan Waktu Penelitian
Lokasi penelitian dilakukan di Kota Padang, Provinsi Sumatera Barat. Waktu pelaksanaan penelitian dilaksanakan dalam jangka waktu 3 bulan.

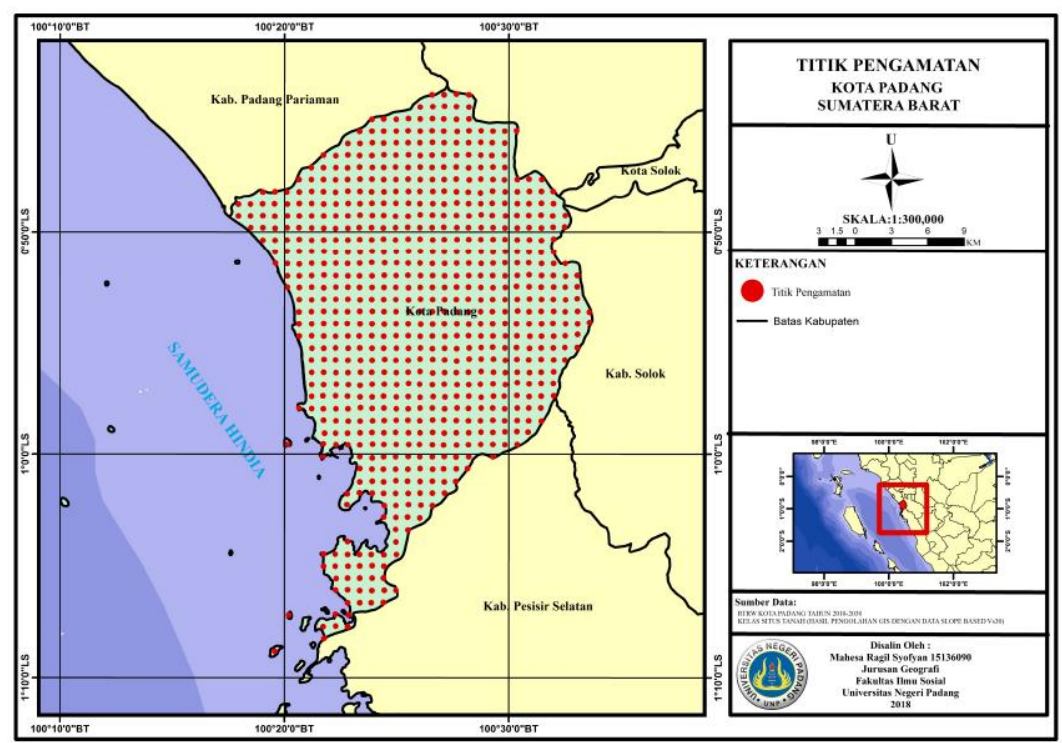

Gambar 1. Peta Lokasi Penelitian

Variabel Penelitian

Tabel 1. Variabel Penelitian

\begin{tabular}{|c|l|l|l|}
\hline No & \multicolumn{1}{|c|}{ Variabel } & \multicolumn{1}{|c|}{ Indikator } & \multicolumn{1}{|c|}{ Sumber Data } \\
\hline 1 & Parameter & a. & Lokasi \\
& Gempabumi & gempabumi & Sekunder \\
& & b. & Kedalaman \\
& & gempabumi & \\
& & c. & Kekuatan gempabumi \\
& & d. Jarak & \\
\hline 2 & Kelas Situs Tanah & a. Batuan & Slope Based \\
& & b. Batuan Keras & Vs \\
& & c. Tanah keras & \\
& & d. Tanah Sedang & \\
& & e. Tanah Lunak & \\
\hline
\end{tabular}

Sumber: Pengolahan Data Sekunder

\section{Teknik Pengumpulan Data}

Parameter gempabumi yang digunakan dalam penelitian ini adalah posisi episenter, magnitudo, kedalaman hiposenter, dan jarak hiposenter. Episenter gempabumi ditentukan dengan melihat Peta Sumber Gempa Indonesia Tahun
2017 (Peta Sumber Dan Bahaya Gempa Indonesia Tahun 2017).

Kecepatan gelombang geser $\left(\mathrm{Vs}_{30}\right)$ ditentukan dengan mengambil data USGS yaitu $\mathrm{Vs}_{30}$ di daerah Kota Padang yang berasal dari Earthquake USGS.

\section{Teknik Pengolahan Data}


Metode penelitian ini dilakukan dalam beberapa tahap, antara lain sebagai berikut:

a. Menentukan skenario gempabumi di zona subduksi Megathrust Mentawai dari Peta Sumber Gempa Indonesia Tahun 2017 (Peta
Sumber Dan Bahaya Gempa Indonesia Tahun 2017).

b. Menentukan klasifikasi kelas situs tanah di Kota Padang menurut SNI 1726:2012 Tata cara perencanaan ketahanan gempa untuk struktur bangunan gedung dan non gedung. (Tabel 2)

Tabel 2. Klasifikasi Kelas Situs Tanah berdasarkan SNI 1726:2012

\begin{tabular}{|c|c|c|}
\hline $\begin{array}{c}\text { Kelas Situs } \\
\text { Tanah }\end{array}$ & Deskripsi Umum & $\mathbf{V s}_{\mathbf{3 0}}(\mathbf{m} / \mathbf{s})$ \\
\hline A & Batuan keras & $>1500$ \\
\hline B & Batuan & $750-1500$ \\
\hline C & $\begin{array}{c}\text { Tanah keras, sangat padat } \\
\text { dan batuan lunak }\end{array}$ & $350-750$ \\
\hline D & Tanah Sedang & $175-350$ \\
\hline E & Tanah Lunak & $<175$ \\
\hline
\end{tabular}

Sumber: SNI 1726:2012 Tata cara perencanaan ketahanan gempa untuk struktur bangunan gedung dan non gedung

c. Menentukan titik pengamatan gempabumi menggunakan point base pada ArcGIS dengan interval jarak $1 \mathrm{~km}$ antar titik di seluruh Kota Padang, dengan alasan untuk mewakili kelas situs tanah. Pengukuran akan berbentuk persegi sesuai dengan koordinat daerah penelitian, selanjutnya kita akan menyeleksi titik pengukuran yang berada diluar batas Kota Padang dan di laut (Peta Sumber Dan Bahaya Gempa Indonesia Tahun 2017);

d. Menentukan masing-masing jarak titik pengamatan ke titik lokasi gempabumi

e. Setelah mendapatkan data $\mathrm{Vs}_{30}$ dan telah menentukan titik acuannya, maka selanjutnya menghitung fungsi atenuasi karena metode Deterministik yang identik dengan fungsi atenuasi ini dimana hubungan empiris untuk parameter gempa yang melemah sejalan dengan bertambahnya jarak, seperti percepatan puncak dan kecepatan puncak. Ada 3 rumusan yang digunakan pada fungsi atenuasi dengan sumber gempa Megathrust yaitu:

1) BCHYDRO (2016)

Fungsi BCHYDRO yang dibuat oleh seorang ilmuawan bernama Abrahamson pada tahun 2016. Fungsi ini menjelaskan, bahwa faktor jarak sangatlah berpengaruh terhadap dampak gempa yang di timbulkan, sehingga faktor dari $\mathrm{Vs}_{30}$ tidak terlalu terlihat pada hasilnya, terlihat pada persamaan dibawah: 


$$
\begin{gathered}
\ln \left(\mathrm{Sa}_{\text {Interface }}\right)=\Theta_{1}+\Theta_{4} \mathrm{C}_{1}+\left(\Theta_{2}+\Theta_{3}(\mathrm{M}-7.8)\right) \ln \left(\mathrm{R}_{\text {rup }}+\mathrm{C}_{4} \exp \left(\Theta_{9}(\mathrm{M} 6)\right)\right)+\Theta_{6} \mathrm{R}_{\text {rup }}+ \\
\text { fmag }(\mathrm{M})+\mathrm{FABA}(\mathrm{Rrup})+\mathrm{fsite}(\mathrm{PGA} 1100, \mathrm{VS} 30)
\end{gathered}
$$

Dengan:

$\mathrm{Sa}:$ spectral acceleration $(\mathrm{g})$

$\mathrm{M}:$ Moment magnitude

$\mathrm{Z}_{\mathrm{h}}$ : kedalaman hypocentral $(\mathrm{Km})$

2) Boore - Atkinson (2003)

Fungsi Atkinson - Boore faktor jarak di kalikan dengan delta/perubahan jarak sehingga jarak yang didapat tidak sesuai dengan dengan jarak asli antara sumber gempa dengan titik acuan. Namun, setelah didapatkan nilai jarak hasil permusan Atkinson-Boore dan dikalikan dengan log, sehingga fungsi jarak pada rumusan ini sangat besar dan sangat berpengaruh. Berbeda dengan rumusan sebelumnya nilai $\mathrm{Vs}_{30}$ dikelompokkan berdasarkan kekerasan tanah, terlihat pada persamaan dibawah:

kalian delta, nilai ini dimasukkan ke ru-

$$
\log \mathrm{Y}=\mathrm{C}_{1}+\mathrm{C}_{2} \mathrm{M}+\mathrm{C}_{3} \mathrm{~h}+\mathrm{C}_{4} \mathrm{R}-\mathrm{glog} \mathrm{R}+\mathrm{C}_{5} \mathrm{sl} \mathrm{Sc}+\mathrm{C}_{6} \mathrm{sl} \mathrm{S}_{\mathrm{D}}+\mathrm{C}_{7} \mathrm{sl} \mathrm{S}_{\mathrm{E}}
$$

Dengan:

$$
\begin{aligned}
& R=\sqrt{D_{\text {fault }}^{2}+\Delta^{2}} \\
& \Delta=0.00724 \times 10^{0.507 \mathrm{M}} \\
& s l=1 \text { for } P G A_{r x} \leq 100 \mathrm{~cm} / \mathrm{s} \text { dan } f \leq 1 \mathrm{~Hz} \\
& g=10^{1.2-0.18 M}
\end{aligned}
$$

Keterangan:

$M=$ Momen magnitudo

$D_{\text {fault }}=$ Jarak terdekat subduksi me-gathrust ke site

$h=$ Kedalaman subduksi dengan be-berapa site class untuk mengetahui variabel $\mathrm{S}_{\mathrm{C}}, \mathrm{S}_{\mathrm{D}}$ dan $\mathrm{S}_{\mathrm{E}}$, adalah sebagai berikut:

a) Class $A$ : $V_{\mathrm{S} 30}>760 \mathrm{~m} / \mathrm{s}\left(\mathrm{S}_{\mathrm{C}}=0, \mathrm{~S}_{\mathrm{D}}=0\right.$, dan $\left.\mathrm{S}_{\mathrm{E}}=0\right)$

b) Class B: $360 \mathrm{~m} / \mathrm{s}<V_{\mathrm{S} 30} \leq 760 \mathrm{~m} / \mathrm{s}\left(\mathrm{S}_{\mathrm{C}}=1, \mathrm{~S}_{\mathrm{D}}=0\right.$ dan $\left.\mathrm{S}_{\mathrm{E}}=0\right)$

c) Class C: $180 \mathrm{~m} / \mathrm{s} \leq \mathrm{V}_{\mathrm{S} 30} \leq 360 \mathrm{~m} / \mathrm{s}\left(\mathrm{S}_{\mathrm{C}}=0, \mathrm{~S}_{\mathrm{D}}=1\right.$ dan $\left.\mathrm{S}_{\mathrm{E}}=0\right)$

d) Class D: $V_{\mathrm{S} 30}<180 \mathrm{~m} / \mathrm{s}\left(\mathrm{S}_{\mathrm{C}}=0, \mathrm{~S}_{\mathrm{D}}=0\right.$ dan $\left.\mathrm{S}_{\mathrm{E}}=1\right)$

3) Zhao et al (2006)

Fungsi Zhao et al faktor ketidakpastian jarak dan Vs30 sangat diperhitungkan. Untuk faktor jarak pada persamaan ini memakai jarak titik acuan terhadap sumber gempa dengan koefisien regresi e. Sehingga jarak yang digunakan

$\log (\mathrm{g})=\mathrm{a} M w+b x-\log \mathrm{e}(\mathrm{r})+\mathrm{e}(\mathrm{h}-\mathrm{hc}) \delta_{\mathrm{h}}+\mathrm{F}_{\mathrm{R}}+\mathrm{S}_{\mathrm{I}}+\mathrm{S}_{\mathrm{S}}+\mathrm{S}_{\mathrm{SL}} \log \mathrm{e}(\mathrm{x})+\mathrm{C}$

Dengan:

$r=x+e^{d M_{w}}$ pada persamaan ini memiliki keakuratan yang besar. Ada pembagian kelas situs tanah apabila jenis tanah pada daerah tersebut rock, hardsoil, mediumsoil, dan softsoil, terlihat pada persamaan dibawah:

$$
r=x+e^{d M_{w}}
$$


Keterangan:

$M_{W}=$ Momen magnitudo

$x=$ Jarak terdekat subduksi ke site

$h=$ Kedalaman subduksi Variabel $\mathrm{C}_{\mathrm{K}}$ digunakan berdasarkan nilai $\mathrm{V}_{\mathrm{S} 30}$ pada daerah tersebut, seperti dibawah ini:

Rock $=600 \mathrm{~m} / \mathrm{s}<\mathrm{V}_{\mathrm{S} 30}<1100 \mathrm{~m} / \mathrm{s}\left(\mathrm{C}_{1}\right)$

Hardsoil $=300 \mathrm{~m} / \mathrm{s}<\mathrm{V}_{\mathrm{S} 30} \leq 600 \mathrm{~m} / \mathrm{s}\left(\mathrm{C}_{2}\right)$

Mediumsoil $=200 \mathrm{~m} / \mathrm{s}<\mathrm{V}_{\mathrm{S} 30} \leq 300 \mathrm{~m} / \mathrm{s}\left(\mathrm{C}_{3}\right)$

Softsoil $=\mathrm{V}_{\mathrm{S} 30} \leq 200 \mathrm{~m} / \mathrm{s}\left(\mathrm{C}_{4}\right)$ Jika $\mathrm{V}_{\mathrm{S} 30} \geq 1100 \mathrm{~m} / \mathrm{s}$ gunakan $\mathrm{C}_{\mathrm{H}}$ untuk variabel $\mathrm{C}_{\mathrm{k}}$ nya

f. Setelah mendapatkan nilai pada (MMI), untuk menunjukkan skala masing-masing rumusan, maka dilakukan pembobotan terhadap masing-masing rumusan tersebut intensitas dengan menggunakan rumusan empiris Murphy \& O'Briuntuk mendapatkan nilai akhir pada masing-masing titik pengamatan.

g. Mengonversi nilai percepatan tanah maksimum (PGA) ke skala Moen pada persamaan:

$\mathrm{MMI}=2,86 \log (\mathrm{PGA})+1,24$

MMI adalah skala intensitas dan dified Mercalli Intensity untuk menPGA adalah percepatan tanah maksimum (gal). (Tabel 4) dapatkan nilai intensitas gempa

Tabel 4. Pengelompokan nilai intensitas gempa berdasarkan tingkat kerusakannya

\begin{tabular}{|c|c|c|c|}
\hline $\begin{array}{c}\text { Intensitas } \\
(\mathbf{M M I})\end{array}$ & $\begin{array}{c}\text { PGA } \\
(\mathbf{G})\end{array}$ & $\begin{array}{c}\text { Perceived } \\
\text { Shaking }\end{array}$ & $\begin{array}{c}\text { Potential } \\
\text { Damage }\end{array}$ \\
\hline I & $<0.0017$ & Not felt & None \\
\hline II-III & $0.0017-0.014$ & Weak & None \\
\hline IV & $0.014-0.039$ & Light & None \\
\hline V & $0.039-0.092$ & Moderate & Very light \\
\hline VI & $0.092-0.18$ & Strong & Light \\
\hline VII & $0.18-0.34$ & Very strong & Moderate \\
\hline VIII & $0.34-0.65$ & Severe & Moderate to \\
heavy
\end{tabular}

Sumber: Peta Sumber Dan Bahaya Gempa Indonesia Tahun 2017 


\section{Teknik Analisis Data}

Tabel 5. Teknik analisis data dalam penelitian.

\begin{tabular}{|l|l|l|l|}
\hline No & \multicolumn{1}{|c|}{ Tujuan Penelitian } & \multicolumn{1}{|c|}{ Metode } & \multicolumn{1}{|c|}{ Hasil } \\
\hline 1 & $\begin{array}{l}\text { Mengetahui persebaran } \\
\text { nilai percepatan tanah } \\
\text { maksimum di Kota Pa- } \\
\text { dang }\end{array}$ & $\begin{array}{l}\text { Metode BCHY- } \\
\text { DRO, Boore At- } \\
\text { kinson, Zhao et al } \\
\text { dan Metode GIS } \\
\text { Interpolasi }\end{array}$ & $\begin{array}{l}\text { Peta } \\
\text { percepatan } \\
\text { tanah } \\
\text { maksimum }\end{array}$ \\
\hline 2 & $\begin{array}{l}\text { Mengetahui persebaran } \\
\text { nilai intensitas gempa } \\
\text { di Kota Padang }\end{array}$ & $\begin{array}{l}\text { Metode empiris } \\
\text { Murphy \& O'Bri- } \\
\text { en dan Metode } \\
\text { GIS In-terpolasi }\end{array}$ & $\begin{array}{l}\text { Peta } \\
\text { intensitas } \\
\text { gempa }\end{array}$ \\
\hline
\end{tabular}

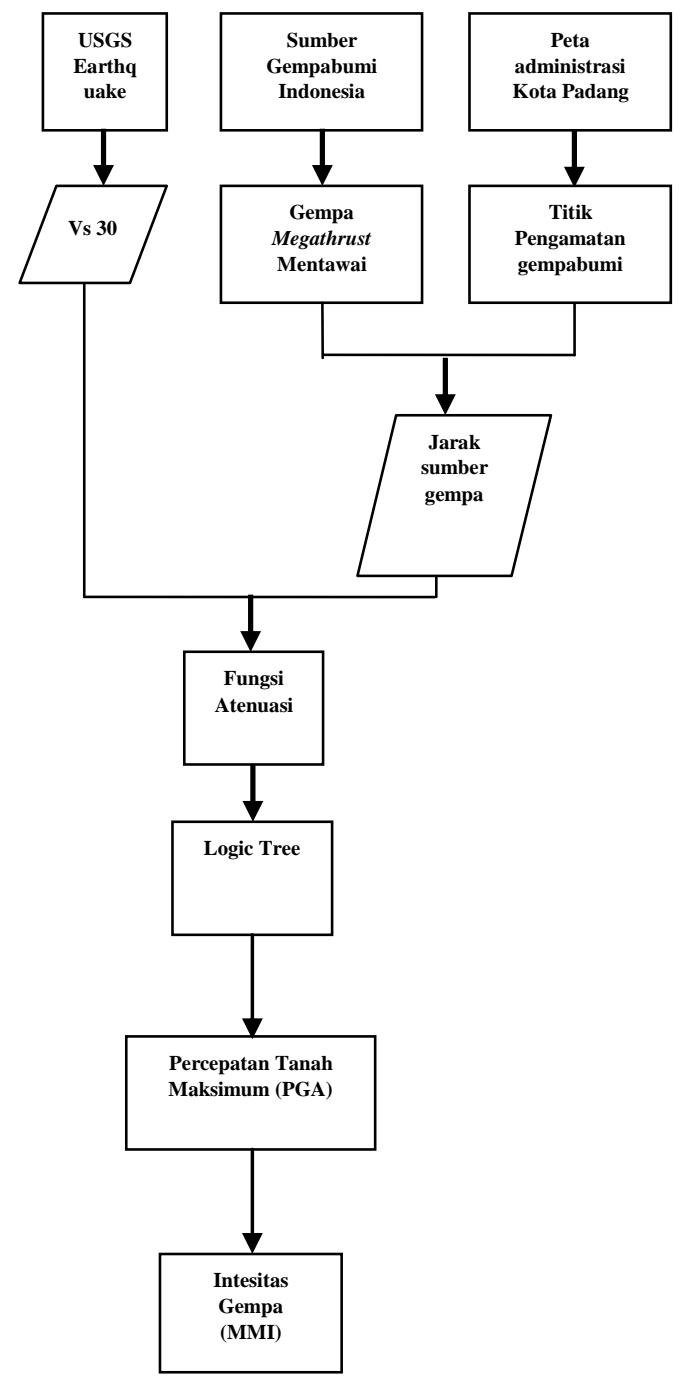

Gambar 2. Diagram Alir Penelitian 
HASIL DAN PEMBAHASAN

Hasil

Percepatan Tanah Maksimum

1) BCHYDRO (2016)

Berdasarkan perhitungan rumusan BCHYDRO didapatkan nilai percepatan tanah maksimum pada zona subduksi Mentawai dengan kedalaman $10 \mathrm{~km}$ dan kekuatan gempa 8,9 MW di Kota Padang, akibat sumber gempa ini nilai percepatan tanah maksimum ter-besar adalah 1,3 g yang mencakup daerah pesisir barat Kota Padang hal ini disebabkan oleh lokasi sumber gempabumi berada sekitar $\pm 150 \mathrm{~km}$ dari zona yang memiliki nilai percepatan tanah maksimum terbesar, sedangkan untuk nilai pe-rcepatan tanah maksimum terkecil adalah $0,18 \mathrm{~g}$ yang mencakup daerah timur Kota Padang hal ini hal disebabkan oleh lokasi sumber gem-pa bumi berada sekitar $\pm 169 \mathrm{~km}$ dari zona yang memiliki percepatan tanah mak-simum terkecil. (Gambar 3)

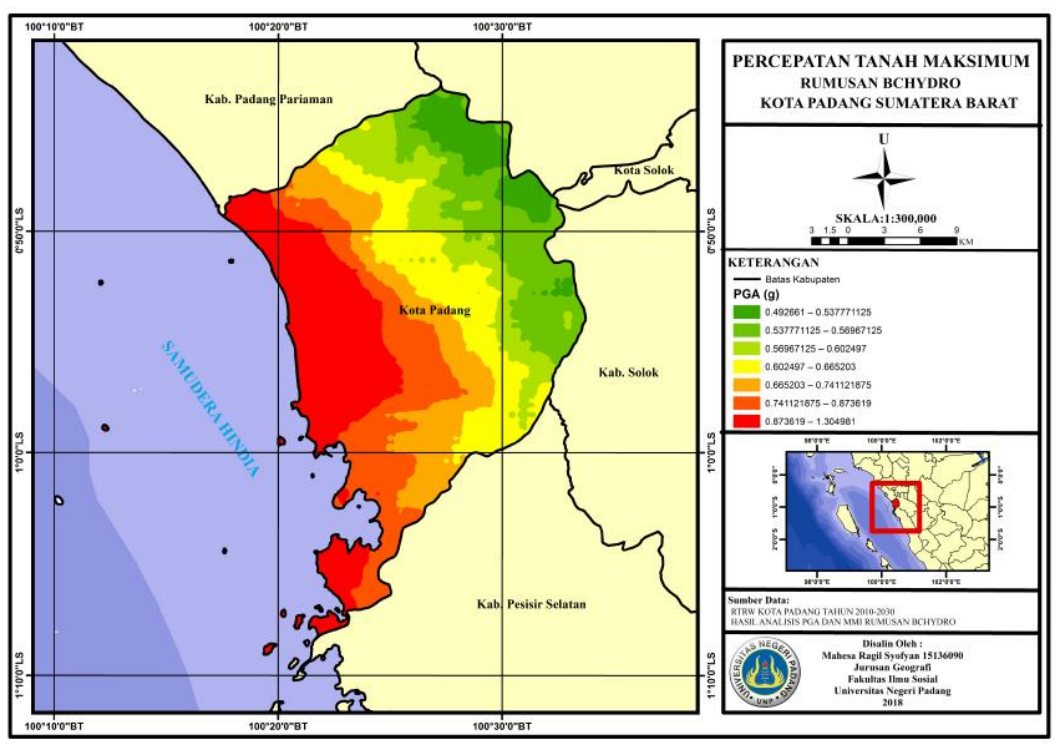

Gambar 3. Peta Percepatan Tanah Maksimum Menurut Rumusan BCHYDRO

2) Atkinsoon Boore (2003)

Hasil yang didapatkan dari perhitungan rumusan Atkinsoon Boore pada zona gempabumi subduksi Mentawai menunjukkan bahwa nilai yang didapat untuk percepatan tanah maksimum di Kota Padang yang terbesar adalah $0,52 \mathrm{~g}$, hal ini disebabkan karena nilai kelas situs tanah pada daerah ini sebesar 180 $\mathrm{m} / \mathrm{s}<\mathrm{Vs}_{30}<360 \mathrm{~m} / \mathrm{s}$ sehingga berda- sarkan klasifikasi kelas situs tanah yang ditentukan oleh Douglas zona ini termasuk dalam Class $\mathrm{C}$, sedang nilai percepatan tanah maksimum terkecil adalah $0,17 \mathrm{~g}$, hal ini di-sebabkan karena nilai kelas situs tanah pada daerah ini sebesar $\mathrm{Vs}_{30}>$ $760 \mathrm{~m} / \mathrm{s}$ sehingga berdasar klasifikasi kelas situs tanah yang ditentukan oleh Douglas zona ini termasuk dalam Class A. (Gambar 4) 


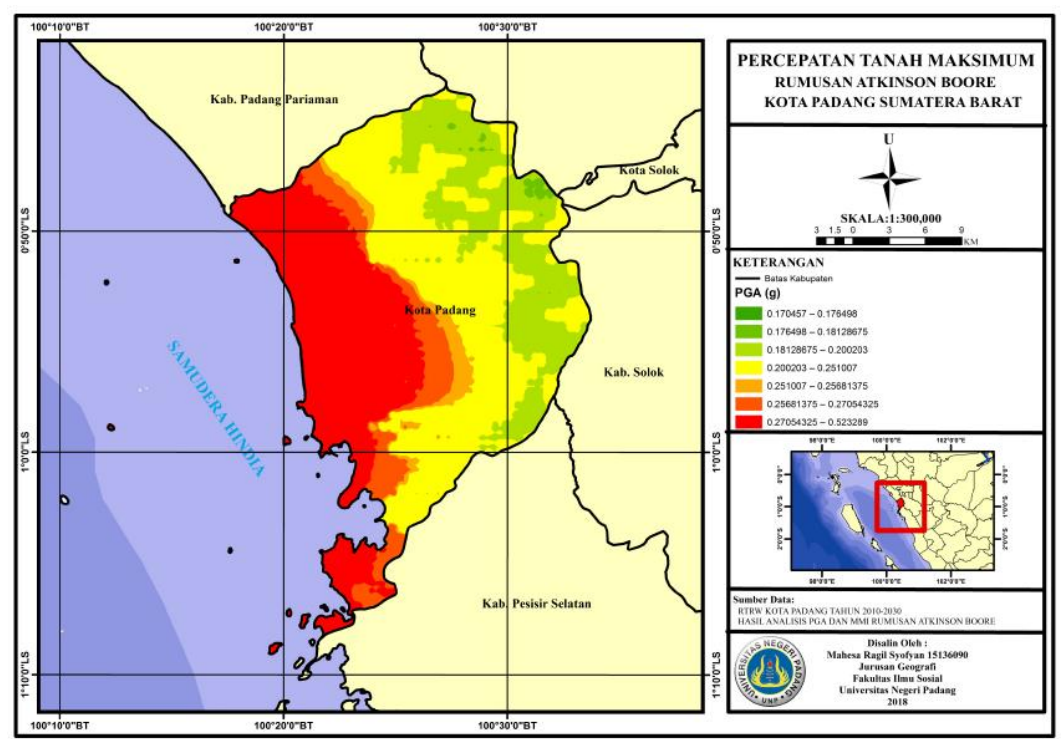

Gambar 4. Peta Percepatan Tanah Maksimum Menurut Rumusan Atkinsoon Boore

\section{3) Zhao et al (2006)}

Hasil yang didapatkan dari perhitungan rumusan Zhao et al pada zona gempabumi subduksi Mentawai menunjukkan bahwa nilai yang didapat untuk percepatan tanah maksimum di Kota Padang yang terbesar adalah $0,57 \mathrm{~g}$, yang berada di daerah dengan jenis tanah medium soil sehingga didapatkan variabel $200 \mathrm{~m} / \mathrm{s}$ $<\mathrm{V}_{\mathrm{S} 30} \leq 300 \mathrm{~m} / \mathrm{s}(\mathrm{C} 3)$. Nilai terkecil yang didapatkan sebesar $0,18 \mathrm{~g}$, yang berada di daerah dengan jenis tanah rock sehingga didapatkan variabel $600 \mathrm{~m} / \mathrm{s}<\mathrm{V}_{\mathrm{S} 30}<1100 \mathrm{~m} / \mathrm{s} \quad(\mathrm{C} 1)$. (Gambar 5)

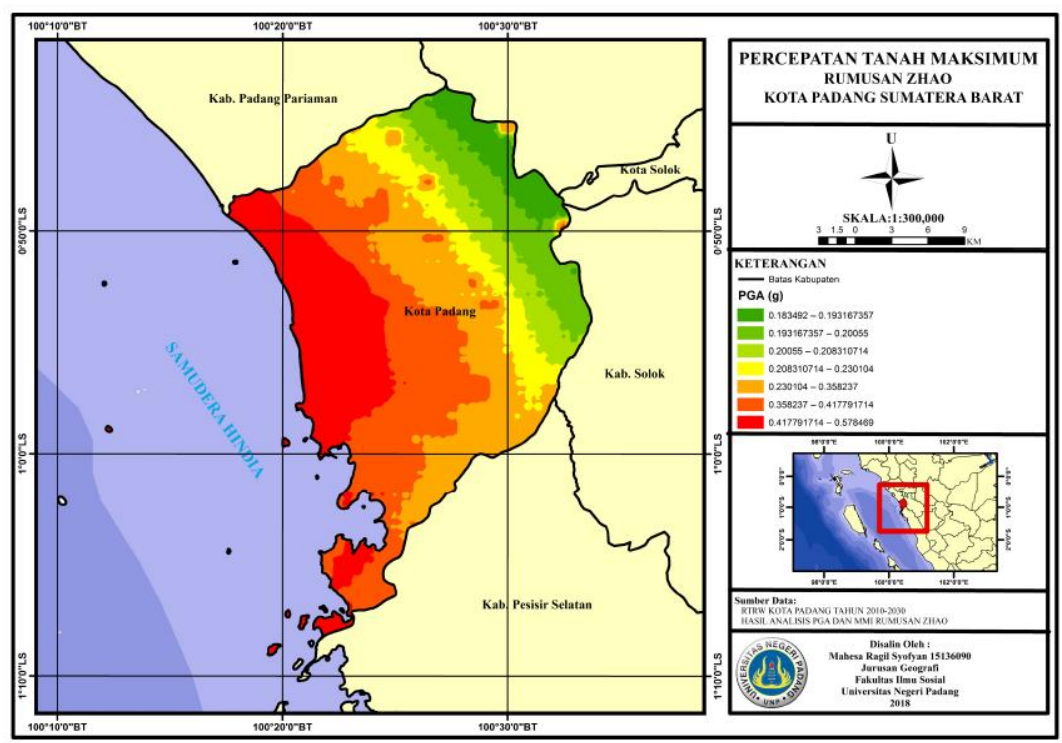

Gambar 5. Peta Percepatan Tanah Maksimum Menurut Rumusan Zhao et al

\section{Intensitas Gempa}

\section{1) BCHYDRO (2016)}

Nilai intensitas gempa di Kota Padang menurut rumusan BCHYDRO mengikuti klasifikasi pengelompokan nilai percepatan ta-nah maksimum berdasarkan tingkat kerusakan yang dipublikasikan oleh Mercalli maka pada zona gempa bumi subduksi Mentawai berkisar 
antara $8 \mathrm{MMI}$ - $10 \mathrm{MMI}$. Zona yang memiliki intensitas gempa terbesar dengan MMI 10 mencakup 23\% dari luas Kota Padang, sedangkan untuk intensitas gempa dengan nilai
MMI 9 mencakup $46 \%$ dari luas Kota Padang dan untuk intensitas gempa terendah dengan MMI 8 mencakup $31 \%$ dari luas Kota Padang. (Gambar 6)

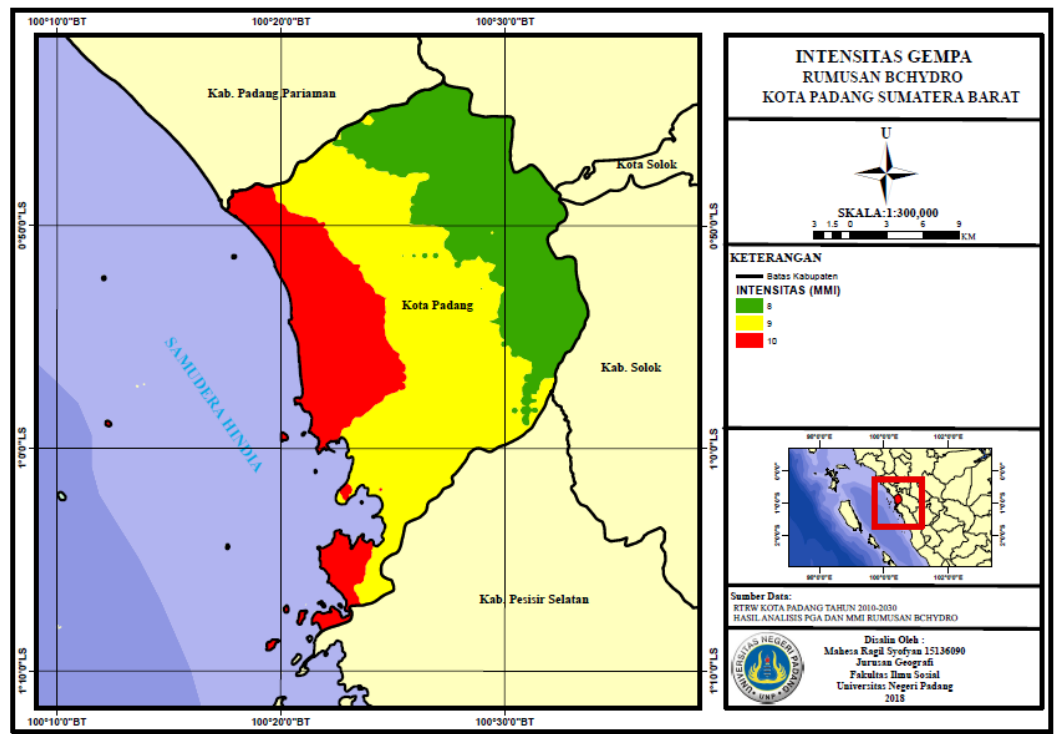

Gambar 6. Peta Intensitas Gempa Menurut Rumusan BCHYDRO

\section{2) Atkinsoon Boore (2003)}

Nilai intensitas gempa di Kota Padang menurut rumusan Atkinsoon Boore mengikuti klasifikasi pengelompokan nilai percepatan tanah maksimum berdasarkan tingkat kerusakan yang dipublikasikan oleh
Mercalli. Zona yang memiliki intensitas gempa terbesar dengan MMI 7 mencakup 69\% dari luas Kota Padang. Intensitas gempa terendah dengan MMI 8 mencakup $31 \%$ dari luas Kota Padang. (Gambar 7)

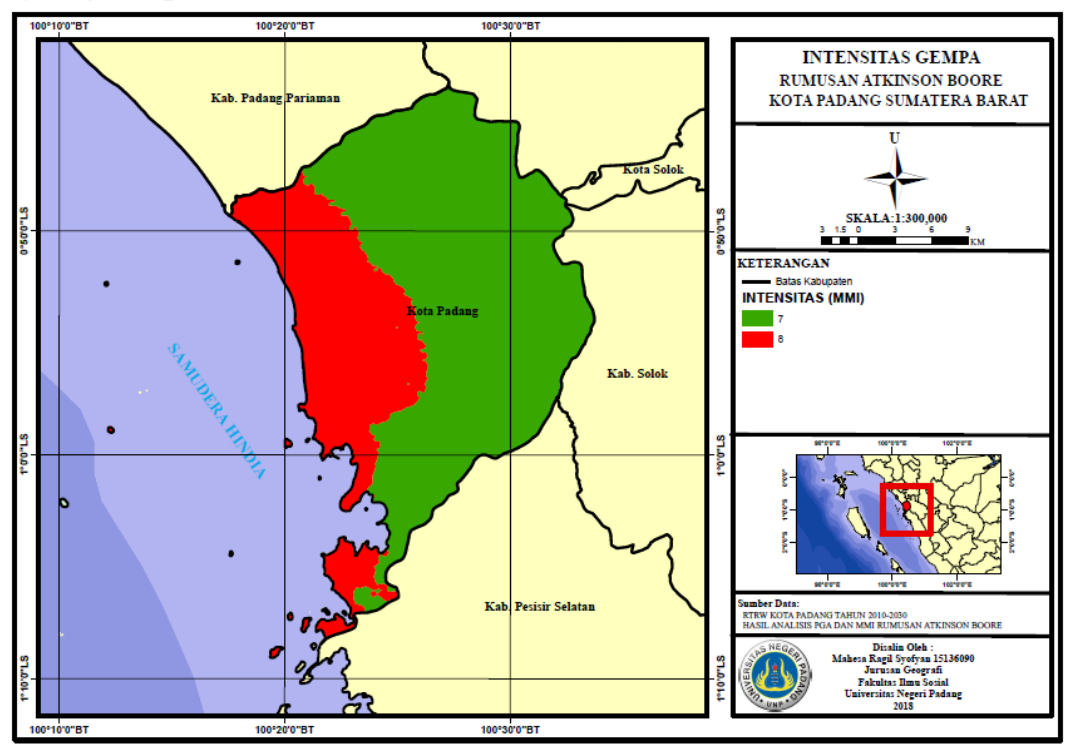

Gambar 7. Peta Intensitas Gempa Menurut Rumusan Atkinsoon Boore 
3) Zhao et al (2006)

Nilai intensitas gempa di Kota Padang menurut rumusan Zhao et al mengikuti klasifikasi pengelompokan nilai percepatan tanah maksimum berdasarkan tingkat kerusa- kan yang dipublikasikan oleh Mercalli. Zona yang memiliki intensitas gempa terbesar dengan MMI 7 mencakup 30\% dari luas Kota Padang. (Gambar 8)

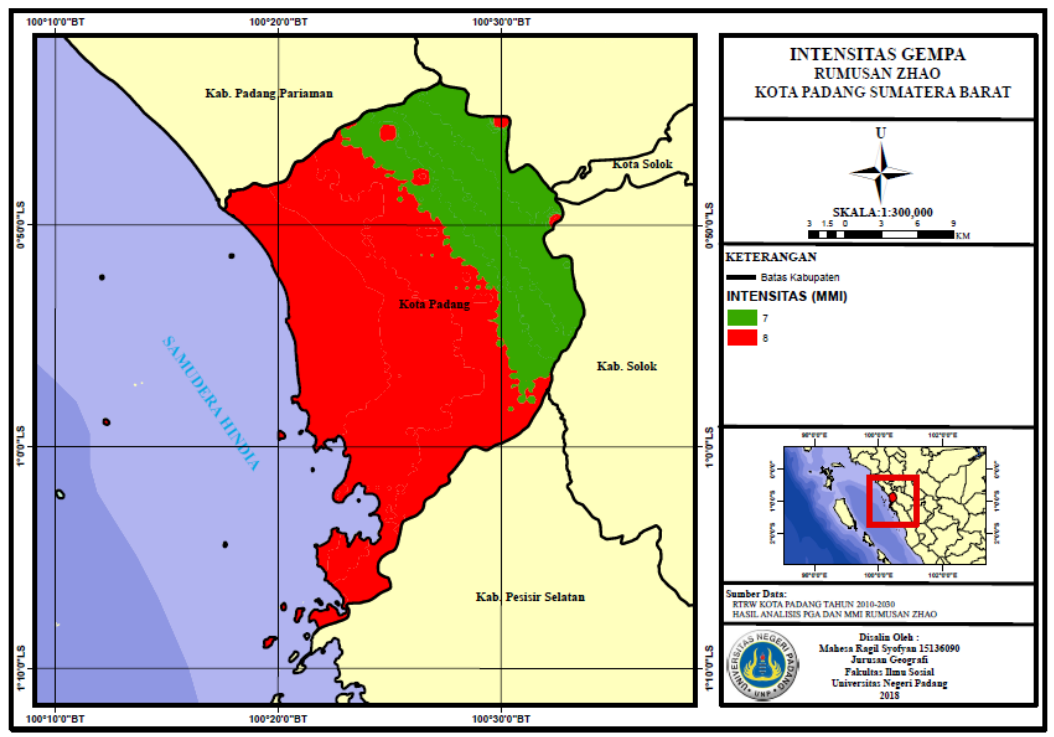

Gambar 8. Peta Intensitas Gempa Menurut Rumusan Zhao et al

\section{Pembahasan}

\section{Percepatan Tanah Maksimum}

Berdasarkan perhitungan logic tree setelah mendapatkan nilai pada masingmasing rumusan, maka dilakukan pembobotan terhadap masing-masing rumusan tersebut untuk mendapatkan nilai akhir pada masing-masing titik pengamatan. (Peta Sumber Dan Bahaya Gempa Indonesia Tahun 2017).

Kota Padang yang terletak di zona gempabumi subduksi Mentawai berdasarkan hasil dari perhitungan logic tree diperoleh nilai percepatan tanah maksimum dengan rentang $0,25 \mathrm{~g}-0,72 \mathrm{~g}$. Daerah yang memiliki percepatan tanah maksimum tertinggi dengan rentang 0,46 $-0,72$ g adalah Kecamatan Nanggalo, Kuranji, Padang Utara, Padang Timur, Padang Barat, dan Padang Selatan. Daerah yang memiliki percepatan tanah maksimum terendah dengan rentang 0,25-0,26 g adalah kecamatan Lubuk Kilangan dan Kecamatan Pauh. (Gambar 9) 


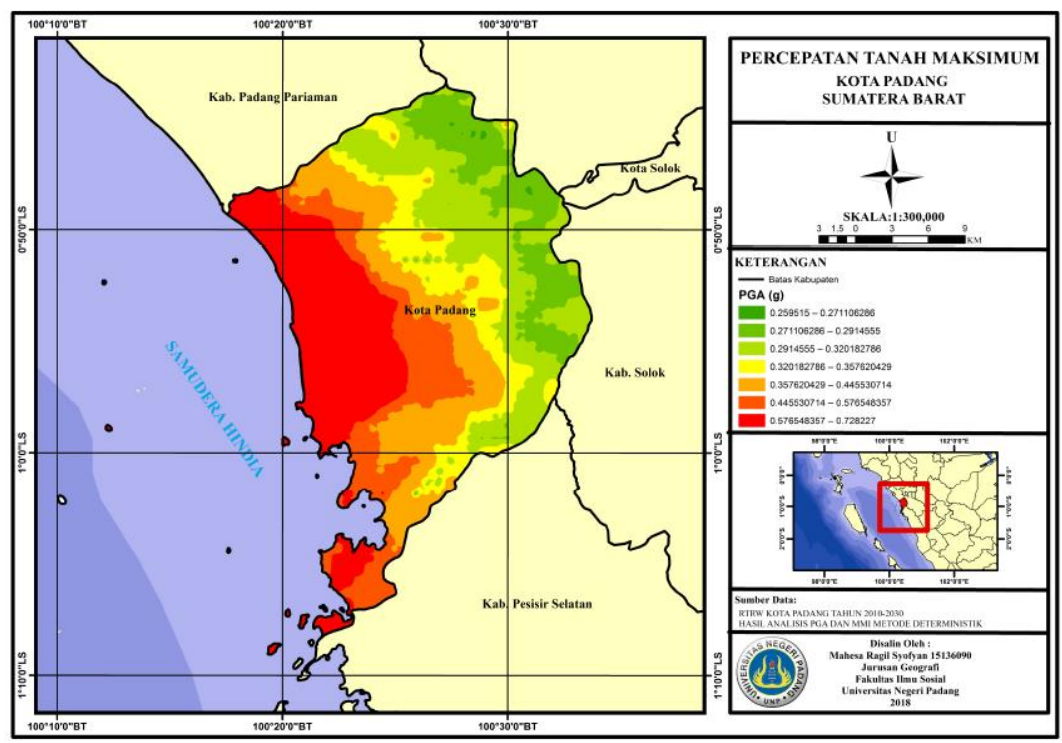

Gambar 9. Peta Percepatan Tanah Maksimum Kota Padang

\section{Intensitas Gempa}

Nilai intensitas gempa di Kota Padang pada zona gempabumi subduksi Mentawai bernilai 7 MMI dan 8 MMI. Daerah yang memiliki intensitas gempa yang paling besar dengan nilai $8 \mathrm{MMI}$ adalah Kecamatan Nanggalo, Padang Utara, Padang Timur, Barat, Kuranji, Lubuk Begalung, Padang Selatan, Lubuk Begalung, Bungus Teluk Kabung, sebagian wilayah Kecamatan Koto Tangah, Pauh, dan Lubuk Ki- langan, sehingga dampak yang ditimbulkan jika terjadi gempa di Megathrust Mentawai dengan kekuatan 8,9 Mw.

Daerah dengan nilai intensitas gempa 7 MMI adalah sebagian wilayah Kecamatan Koto Tangah, Kecamatan Pauh, Kecamatan Lubuk Kilangan, dan sebagian kecil wilayah Kecamatan Bungus Teluk Kabung, sehingga dampak yang ditimbulkan jika terjadi gempa di Megathrust Mentawai dengan kekuatan 8,9 Mw. (Gambar 10)

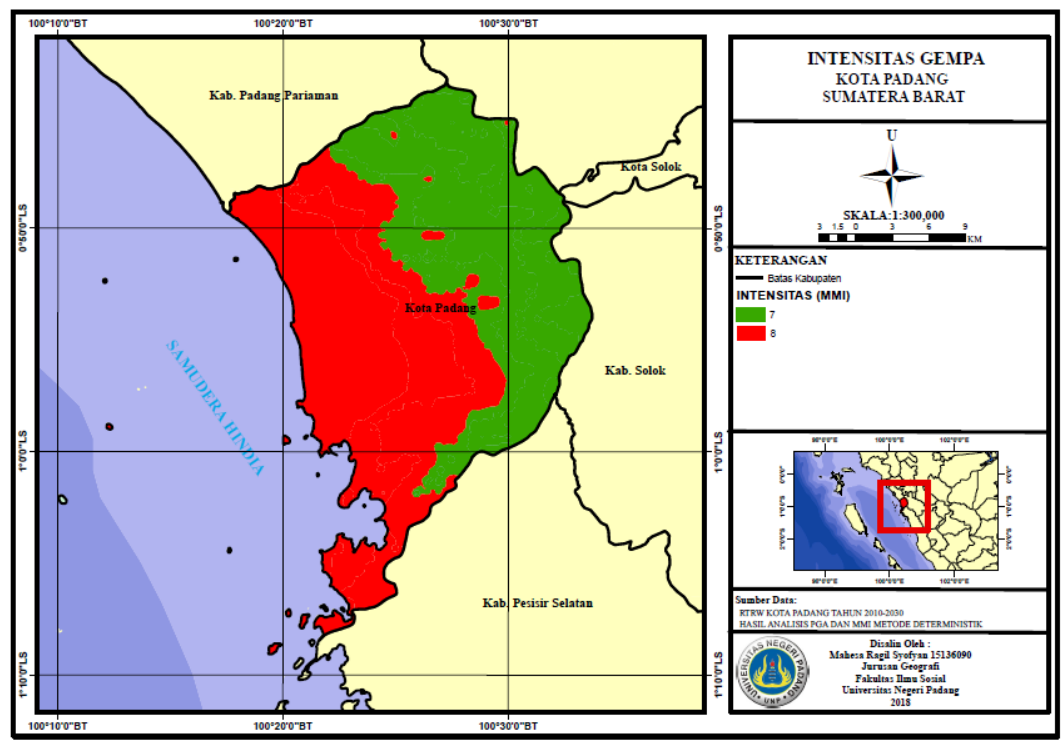

Gambar 10. Peta Intensitas Gempa Kota Padang 


\section{KESIMPULAN}

Persebaran nilai percepatan tanah maksimum (PGA) di Kota Padang akibat gempabumi pada zona subduksi Mentawai dengan kedalaman $10 \mathrm{~km}$ dan kekuatan gempa 8,9 $\mathrm{Mw}$ tertinggi dengan rentang 0,46-0,72 g mencakup Kecamatan Nanggalo, Kuranji, Padang Utara Padang Timur, Padang Barat, dan Padang Selatan. Sedangkan nilai percepatan tanah maksimum teredah dengan rentang 0,25-0,26 $\mathrm{g}$ mencakup kecamatan Lubuk Kilangan dan Kecamatan Pauh. Persebaran nilai intensitas gempa (MMI) memiliki nilai 7 MMI dan 8 MMI.

\section{DAFTAR PUSTAKA}

Abrahamson, N., Gregor, N. and Addo, K., 2016. Bchydro ground motion prediction equations for subduction earthquakes. Earthquake Spectra, 32(1), pp.23-44.

Atkinson, G.M. dan Boore, D.M., 2003. Empirical Ground-Motion Relations for Subduction-Zone Earthquakes and Their Application to Cascadia and Other Regions. Bulletin of the Seismological Society of Ame-rica. Volume 93, nomor 4, pp. 17031729

Badan Standardisasi Nasional (BSN). 2012. Tata cara perencanaan ketahanan gempa untuk struktur bangunan gedung dan non gedung SNI 1726:2012. Badan Standardisasi Nasional, Jakarta.

Hadi, Farid, dan Fauzi. (2012). Pemetaan Percepatan Getaran Tanah dan Indeks Kerentanan Seismik Akibat Gempabumi untuk Mendukung Rencana Tata Ruang dan Wilayah (RTRW) Kota Bengkulu. Bengkulu: Ilmu Fisika Universitas Bengkulu
Husrin, S., Kongko, W and Putera, A (2013). Tsunami Vulnerability of Critical Infrastructures in the City of Padang, West Sumatera. In The Proceeding of SIBE.

Irsyam, Masyhur, dkk. 2017. Peta Sumber Dan Bahaya Gempa Indonesia Tahun 2017. Bandung: Cetakan Pertama

Juita, E., Zulva, R., \& Edial, H. (2018). Profile of Development of Critical Thinking Student Skills Assessment Instrument in the Course Geography of Disaster. Sumatra Journal of Disaster, Geography and Geography Education, 2(1), 147-150.

Minster, J.B. dan Jordan, T.H., 1978., Present-day plate motions. Jour-nal of Geophysical Research 83. ISSN: 0148-0227

Nazir, Moh. 2009. Metode Penelitian. Jakarta: Ghalia Indonesia

Novita, H. (2008). Analisis Percepatan Tanah Terhadap Kerusakan Bangunan Akibat Gempa Di Padang Panjang, Tesis S2, Universitas Andalas.

Sieh, K. dan Natawidjaja, D., 2000. Neotectonics of Sumatra Fault, Indonesia.

Tim Pusat Studi Gempa Nasional., 2017. Peta Sumber Dan Bahaya Gempa Indonesia Tahun 2017

Zhao, J.X., Zhang, J., Asano, A., Ohno, Y., Oouchi, T., Takahashi, T., Ogawa, H., Irikura, K., Thio, H. dan Somerville, P., 2006. Attenuation Relations of Strong Motion in Japan using site classification based on predominant period. Bulletin Seismol. Soc. Am. 96, 898. 